\title{
Editorial: Computing in the "Cloud"
}

\section{Silver Lining or Stormy Weather Ahead?}

C loud computing. Remote hosting. Software as a Service (SaaS). Outsourcing. Terms that all describe various parts of the same IT elephant these days. The sexy ones-cloud computing, for example-emphasize New Age-y, "2.0" virtues of collaboration and sharing with perhaps slightly mystic overtones: Exactly where and what is the "cloud," after all? Others, such as the more utilitarian "remote hosting" and "outsourcing," appeal more to the bean counters and sustainabilityminded among us. But they're really all about the same thing: the tradeoff between cost and control.

That the issue increasingly resonates with IT operations at all levels these days can be seen in various ways. I'll cite just a few:

- At the meeting of the LITA Heads of Library Technology (HoLT) Interest Group at the 2009 ALA Annual Conference in Chicago, two topics dominated the list of proposed HoLT programs for the 2010 Annual Conference. One of these was the question of virtualization technology, and the other was the whole white hat-black hat dichotomy of the cloud. ${ }^{1}$ Practically everyone in the room seemed to be looking at-or wanting to know more about-the cloud and how it might be used to benefit institutions.

- My institution is considering outsourcing e-mail. All of it-to Google. Times are tough, and we're being told that by handing e-mail over to the Googleplex, our hardware, licensing, evergreening, and technical support fees will total zero. Zilch. With no advertising. Heady stuff when your campus hosts thirty-plus central and departmental mail servers, at least as many Blackberry servers, and total costs in people, hardware, licensing, and infrastructure are estimated to exceed Can $\$ 1,000,000$ annually.

- In the last couple of days, library electronic discussion lists such as web4lib have been abuzzor do we now say a-Twitter?-about Amazon's Orwellian Kindle episode, in which the firm deleted copies of 1984 and Animal Farm from subscribers' Kindle e-book readers without their knowledge or consent. ${ }^{2}$ Indeed, Amazon's action was in violation of its own terms of service, in which the company "grants [the Kindle owner] the non-exclusive right to keep a permanent copy of the applicable Digital Content and to view, use, and display such Digital Content an unlimited number of times, solely on the Device or as authorized by Amazon as part of the Service and solely for [the Kindle owner's] personal, noncommercial use." ${ }^{3}$

All of this has me thinking back to the late 1990s marketing slogan of a manufacturer of consumer-grade mass storage devices-remember removable hard drives? Iomega launched its advertising campaign for the $1 \mathrm{~GB}$ Jaz drive with the catch-line "Because it's your stuff." Ultimately, whether we park it locally or send it to the cloud, I think we need to remember that it is our stuff. What I fear is that in straitened times, it becomes easy to forget this as we struggle to balance limited staff, infrastructure, and budgets. We wonder how we'll find the time and resources to do all the sexy and forward-looking things, burdened as we are with the demands of supporting legacy applications, "utility" services, and a huge and constantly growing pile of all kinds of content that must be stored, served up, backed up (and, we hope, not too often, restored), migrated, and preserved.

The buzz over the cloud and all its variants thus has a certain Siren-like quality about it. The notion of signing over to someone else's care-for little or no apparent cost-our basic services and even our own content (our stuff) is very appealing. The song is all the more persuasive in a climate where we've moved from just the normal bad news of merely doing more with less to a situation where staff layoffs are no longer limited to corporate and public libraries, but indeed extend now to our greatest institutions. ${ }^{4}$

At the risk of sounding like a paranoid naysayer to what might seem a no-brainer proposition, I'd like to suggest a few test questions for evaluating whether, how, and when we send our stuff into the cloud:

1. Why are we doing this? What do we hope to gain?

2. What will it cost us? Bear in mind that nothing is free-except, in the open-source community, where free beer is, unlike kittens, free. If, for example, the Borg offer to provide institutional mail without advertisements, there is surely a cost somewhere. The Borg, sensibly enough, are not in business to provide us with pro bono services.

3. What is the gain or loss to our staff and patrons in terms of local customization options, functionality, access, etc?

4. How much control do we have over the service offered or how our content is used, stored,

Marc Truitt (marc.truitt@ualberta.ca) is Associate University Librarian, Bibliographic and Information Technology Services, University of Alberta Libraries, Edmonton, Alberta, Canada, and Editor of ITAL. 
repurposed, or made available to other parties?

5. What's the exit strategy? What if we want to pick up and move elsewhere? Can we reclaim all of our stuff easily and portably, leaving no sign that we'd ever sent it to the cloud?

We are responsible for the services we provide and for the content we have been entrusted. We cannot shrug off this duty by simply consigning our services and our stuff to the cloud. To do so leaves us vulnerable to an irreparable loss of credibility with our users; eventually some among them would rightly ask, "So what is it that you folks do, anyway?"

We're responsible for it-whether it's at home or in the cloud-because it's our stuff. It is our stuff, right?

\section{References and Notes}

1. I should confess, in the interest of full disclosure, that it was Eli Neiburger of the Ann Arbor District Library who suggested "hosted services as savior or slippery slope" for next year's HoLT program. I've shamelessly filched Eli's topic, if not his catchy title, for this column. Thanks, Eli. Also, again in the interest of full disclosure, I suggested the virtualization topic, which eventually won the support of the group. Finally, some participants in the discussion observed that virtualization technology and hosting are in many ways two sides of the same topical coin, but I'll leave that for others to debate.

2. Brad Stone, "Amazon Erases Orwell Books from Kindle," New York Times, July 17, 2009, http://www.nytimes .com/2009/07/18/technology/companies/18amazon.html? $\mathrm{r}=1$ (accessed July 21, 2009).

3. Amazon.com, "Amazon Kindle: License Agreement and Terms of Use," http://www.amazon.com/gp/help/customer/ display.html?nodeId=200144530 (accessed July 21, 2009).

4. "Budget Cutbacks Announced in Libraries, Center for Professional Development," Stanford University News, June 10, 2009, http:/ / news.stanford.edu/news/2009/june17/layoffs-061709 .html (accessed July 22, 2009; "Harvard Libraries Cuts Jobs, Hours," Harvard Crimson (Online Edition), June, 26 2009, http: / / www.thecrimson.com/article.aspx?ref=528524 (accessed July 22, 2009). 